\title{
The Developmental Potential of Oocytes is Impaired in Cattle with Liver Abnormalities
}

\author{
Borjigin SARENTONGLAGA ${ }^{1,2)}$, Kazuko OGATA ${ }^{1,2)}$, Yoriko TAGUCHI'), Yoku KATO ${ }^{1,2)}$ and \\ Yoshikazu NAGAO', ${ }^{1,2}$ \\ 1) Department of Animal Production Science, United Graduate School of Agricultural Science, Tokyo University of \\ Agriculture and Technology, Tokyo 183-8509, Japan \\ 2) University Farm, Faculty of Agriculture, Utsunomiya University, Tochigi 321-4415, Japan
}

\begin{abstract}
Here, we investigated the effect of liver abnormality on the developmental potential of bovine oocytes. Good quality oocytes from healthy cows and from animals with a liver abnormality were matured and fertilized in vitro and then cultured to the blastocyst stage. On day 7 after fertilization, embryo cleavage and development were assessed. The concentrations of glucose, nonesterified fatty acid (NEFA), $\gamma$-glutamyl transpeptidase ( $\gamma$-GTP), $\beta$-hydroxybutyrate (BHBA) and glutathione were measured in follicular fluids (FF). The proportion of good quality oocytes and the frequency of development to the blastocyst stage were lower in the liver anomaly group than those of the control group $(\mathrm{P}<0.05)$. The concentrations of $\gamma$-GTP and BHBA in the FF of the liver anomaly group were higher than those of the control group $(\mathrm{P}<0.05)$. The concentration of glutathione in the FF of the liver anomaly group was lower than that of the control group $(\mathrm{P}<0.05)$. Moreover, there was a negative correlation between these concentrations and the proportions of oocytes that developed to the blastocyst stage $(\mathrm{P}<0.05)$. Supplementation of the culture medium with $\gamma$-GTP or BHBA did not affect the rate of oocyte maturation but did cause a concentration-dependent reduction in the frequency of fertilized oocytes that developed to the blastocyst stage. Our findings indicate that the quality of oocytes and their potential for development are lower in cattle with liver disorders than those in healthy cattle; one possible cause may be the high concentration of $\gamma$-GTP and/or BHBA in their FF.
\end{abstract}

Key words: Bovine, Embryo development, Follicular fluid, Liver abnormality, Oocyte

(J. Reprod. Dev. 59: 168-173, 2013)

$\mathbf{T}$ he application of in vitro production techniques to bovine oocytes and embryos is now a routine practice. However, the rate of success for culturing fertilized oocytes to the blastocyst stage varies widely between 0 and $50 \%$ for oocytes obtained from cattle at slaughter [1-5]. The rate of success probably depends on the developmental potential of the oocytes collected from the cattle. A number of factors affect the quality of follicular oocytes: estrous cycle [6,7], follicular cycle [8] and status of the cumulus cells [9-11]. In this study, we focused on the effects of liver abnormality in cattle as a potentially deleterious factor for in vitro reproductive techniques.

High-yielding dairy cows suffer a negative energy balance (NEB) during the first four weeks of lactation because of their energy expenditure for milk production and their limited feed intake [12]. As a consequence of this NEB, cows metabolize body fat to enable milk production; however, metabolizing fat results in lipomobilization and a high probability of fatty infiltration into the liver. It has been calculated that 60 to $125 \mathrm{~g}$ /day of fat accumulates in the liver during the first 10 days of lactation [13], a metabolic load that can cause liver problems in dairy cows [14]. In the abattoir where we regularly collect bovine ovaries, the livers of approximately $36 \%$ of dairy cattle are discarded because of abnormalities such as fatty liver,

Received: November 8, 2012

Accepted: November 30, 2012

Published online in J-STAGE: December 29, 2012

C2013 by the Society for Reproduction and Development

Correspondence: Y Nagao (e-mail: ynagao@cc.utsunomiya-u.ac.jp) hepatitis and liver degeneration (Table 1). These liver disorders are subclinical in most cases [13] and not included in the main reasons for slaughter of the dairy cattle [15]; by contrast, infertility in lactating cattle does lead to slaughter $[15,16]$. However, the development of liver disorders significantly increases the risk of developing other disorders [14] that can potentially result in infertility [13]. So, we speculated that such conditions might underlie problems in fertility in lactating cattle and could also cause the variation in developmental potential of the oocytes of cattle sent to slaughter. To date, there has been no examination of the possible relationship between the developmental potential of oocytes and liver disorders ascertained in cattle after slaughter. This study compared the rates of successful oocyte development after IVM/IVF in cows with normal and diseased livers and also examined the effects of some FF factors on the rates of success.

\section{Materials and Methods}

\section{Collection and classification of bovine ovaries}

Bovine ovaries were obtained from a slaughter house; those with overt abnormalities, such as follicular cysts and atrophy, were not included in the experiments. The ovaries were classified according to the condition of the liver of the cow. The assessment was performed by an experienced veterinarian, and two groups of cows were identified: a control group with normal livers and a liver disorder (LD) group in which the organ was assessed for disposal because of a structural abnormality, such as fatty liver, hepatitis or 
Table 1. No. (\%) of animals with liver disease in cattle sent for slaughter ${ }^{1}$

\begin{tabular}{cccccc}
\hline \multirow{2}{*}{ No. cattle inspected } & \multicolumn{5}{c}{ No. liver diseases } \\
\cline { 2 - 5 } & Total & Hepatitis & Degeneration & Telangiectasis & Fatty liver \\
\hline 5343 & $1936(36.2)^{*}$ & $1276(65.9)^{\#}$ & $422(21.8)^{\#}$ & $238(12.2)^{\#}$ & $3(0.2)^{\#}$ \\
\hline${ }^{1}$ Data from an annual report of the Meat Inspection Office, Yamanashi Prefecture, 2009. *Percentage of \\
cattle inspected. "Percentage of the total No. of cattle with liver diseases.
\end{tabular}

liver degeneration.

The ovaries were maintained at 15-20 C and transported to the laboratory in a saline solution supplemented with antibiotics and antimycotics (AB; Invitrogen, Carlsbad, CA, USA); the time between recovery of ovaries and transport to the laboratory was approximately $1 \mathrm{~h}$. The ovaries were then held in saline supplemented with $0.3 \mathrm{mM}$ reduced glutathione (GSH; G4251, Sigma-Aldrich, St. Louis, MO, USA) and $1 \% \mathrm{AB}$ at $15 \mathrm{C}$ for $20 \mathrm{~h}$ with shaking [17].

\section{Oocyte collection and in vitro maturation (IVM)}

Oocyte collection and IVM of oocytes were carried out as previously described [18]. In short, cumulus oocyte-complexes (COCs) with FF were aspirated from follicles $2-6 \mathrm{~mm}$ in diameter using a 20 -gauge needle attached to a $5 \mathrm{ml}$ syringe. Oocytes with intact cumulus cells and evenly granulated cytoplasm were selected as good quality for further study. Selected oocytes were washed and cultured in $50 \mu \mathrm{l}$ drops of modified TCM-199 (m-TCM199) covered with mineral oil (M8410, Sigma-Aldrich) in a culture dish (Falcon 351007, Becton, Dickinson and Company, Franklin Lakes, NJ, USA) for $24 \mathrm{~h}$ at $39 \mathrm{C}$ under $5 \% \mathrm{CO}_{2}$ in air with high humidity. The m-TCM199 consisted of HEPES-buffered medium 199 (No. 12340, Invitrogen) supplemented with $0.1 \%(\mathrm{w} / \mathrm{v})$ polyvinyl alcohol (P8136, Sigma-Aldrich), $0.5 \mathrm{mM}$ sodium pyruvate (Nacalai Tesque, Tokyo, Japan), 1\% AB, 0.02 IU/ml FSH (Antrin, Kyoritsu Seiyaku, Tokyo, Japan) and $1 \mu \mathrm{l} / \mathrm{ml}$ estradiol-17 $\beta$ (E2758, Sigma-Aldrich).

\section{Collection of follicular fluid (FF)}

After the collection of COCs, residual FF from each cow was centrifuged at $1000 \times \mathrm{g}$ at $4 \mathrm{C}$ for $10 \mathrm{~min}$. The supernatant (approximately $300-800 \mu \mathrm{l}$ ) was aspirated and stored at $-20 \mathrm{C}$ until analysis.

\section{In vitro fertilization (IVF) of bovine oocytes}

IVF was carried out as previously described [5]. Briefly, frozenthawed semen from a single bull was washed with a discontinuous Percoll solution. Mature oocytes were then inseminated with the washed spermatozoa $\left(1-2 \times 10^{6}\right.$ cells $\left./ \mathrm{ml}\right)$ in Brackett and Oliphant medium [19] supplemented with $10 \mu \mathrm{g} / \mathrm{ml}$ heparin (Sigma-Aldrich; $\mathrm{m}-\mathrm{BO})$. COCs (7-13 COCs/drop) were cultured with spermatozoa in $100-\mu 1$ drops of medium covered with mineral oil in a culture dish (Falcon 351007, Becton, Dickinson and Company). All cultures were performed at $39 \mathrm{C}$ under $5 \% \mathrm{CO}_{2}$ in air at high humidity for $18 \mathrm{~h}$. A few COCs were fixed and stained with aceto-orcein to assess maturation status.

\section{In vitro culture (IVC) of embryos}

Culture of embryos derived from IVM/IVF oocytes was carried out essentially as described by Nagao et al. [20]. Briefly, denuded embryos were cultured in a protein-free synthetic oviductal fluid modified with the amino acid component $\mathrm{m}$-SOF [18] under 5\% $\mathrm{CO}_{2}, 5 \% \mathrm{O}_{2}$ and $90 \% \mathrm{~N}_{2}$ at $39 \mathrm{C}$ with high humidity. The embryos were placed into $50-\mu$ l droplets of the medium (7 to 30 embryos/ drop) and covered with mineral oil in culture dishes (Falcon 351007, Becton, Dickinson and Company). A few denuded IVM/IVF oocytes were fixed and stained with aceto-orcein to confirm their fertilization status. Cleavage ( $\geq 2$-cell) and development to the blastocyst stage were examined under a stereomicroscope $(\times 60)$ at 7 days after insemination.

\section{Analysis of follicular fluid (FF)}

The concentrations of glucose, nonesterified fatty acid (NEFA), $\beta$-hydroxybutyrate (BHBA), $\gamma$-glutamyl transpeptidase $(\gamma$-GTP) and glutathione in each FF sample were measured as appropriate using the Mutarotase-GOD assay (Glucose CII Test Wako, Wako Pure Chemical Industries, Tokyo, Japan) [21], the ACS-ACOD assay (NEFA C-Test Wako, Wako Pure Chemical Industries) [22], an enzyme assay with D-3-hydroxybutyric acid dehydrogenase and nitrotetrazolium blue (DiaSys Diagnostics System GmbH, Holzheim, Germany) [23], the SPOTCHEM $^{\mathrm{TM}}$ II assay (Glutamyl Transpeptidase Kit, ARKRAY, Kyoto, Japan) [24, 25] and the enzymatic cycling method with DTNB (GSSG/GSH Quantification Kit, Dojindo Molecular Technologies, Rockville, MD, USA), respectively.

\section{Experimental design}

Experiment 1-1: To examine the developmental potential of oocytes from normal and LD cattle, good quality COCs screened from COCs collected from each ovary were matured, fertilized and cultured in vitro, and the frequencies of embryos undergoing cleavage and developing to the blastocyst stage were evaluated.

Experiment 1-2: The concentrations of glucose, NEFA, BHBA, $\gamma$-GTP and glutathione in each FF sample were measured. These five components were selected to act as biomarkers: glucose, NEFA and BHBA were selected as markers for nutritive condition and energy balance, $\gamma$-GTP was selected as a marker of liver condition, and glutathione was measured as a substance relevant to $\gamma$-GTP. If the volume of supernatant recovered from the FF was less than $500 \mu \mathrm{l}$, then only 2 or 3 of the markers were measured.

\section{Experiment 2}

The effects of BHBA and $\gamma$-GTP on maturation and development of the oocytes were assessed by pooling COCs collected from normal cattle. To examine effects on oocyte maturation, COCs were matured in m-TCM199 supplemented with $\operatorname{BHBA}(0,25,50$ or $250 \mathrm{mg} / \mathrm{l})$ or $\gamma$-GTP $(0,50,250$ or $500 \mathrm{IU} / \mathrm{l})$, fertilized in $\mathrm{m}-\mathrm{BO}$ and then cultured in $\mathrm{m}$-SOF. To examine effects on early embryo development, COCs 
Table 2. Effects of liver abnormality on the quality of oocytes and their development potential

\begin{tabular}{|c|c|c|c|c|c|c|}
\hline \multirow{2}{*}{ Liver condition } & \multirow{2}{*}{$\mathrm{N}$} & \multicolumn{2}{|c|}{ Oocytes collected } & \multicolumn{3}{|c|}{ Embryo development } \\
\hline & & Total $^{\#}$ & $\operatorname{Good}^{\#}(\%)^{*}$ & No. cultured ${ }^{\#}$ & No. cleaved ${ }^{\#}(\%)^{\# \#}$ & No. blastocysts ${ }^{\#}(\%)^{\#}$ \\
\hline Control & 8 & $34.8 \pm 7.5$ & $29.1 \pm 6.3(84.5)^{\mathrm{a}}$ & $21.2 \pm 3.5$ & $16.0 \pm 7.7(74.8)$ & $8.0 \pm 1.2(38.9)^{\mathrm{a}}$ \\
\hline Abnormal & 8 & $25.4 \pm 4.6$ & $15.8 \pm 2.8(61.6)^{\mathrm{b}}$ & $15.0 \pm 2.1$ & $10.8 \pm 5.7(69.7)$ & $2.1 \pm 0.5(13.2)^{b}$ \\
\hline
\end{tabular}

$\mathrm{N}$ : No. of cattle examined. \#Data were summarized as means \pm SEM of 8 cattle. *Percentages of total No. oocytes. \#\# Percentages of No. cultured. ${ }^{\mathrm{a}-\mathrm{b}}$ Values with different superscripts within the same column differ significantly $(\mathrm{P}<0.05)$.

Table 3. Follicular fluid constituents from control cattle and those with liver abnormalities

\begin{tabular}{lcccccc}
\hline \multirow{2}{*}{ Liver condition } & $\mathrm{N}$ & \multicolumn{5}{c}{ Compounds } \\
\cline { 3 - 7 } & & Glucose $(\mathrm{mg} / \mathrm{dl})^{*}$ & NEFA $(\mu \mathrm{Eq} / \mathrm{l})^{*}$ & BHBA $(\mathrm{mg} / \mathrm{l})^{*}$ & $\gamma$-GTP $(\mathrm{IU} / \mathrm{l})^{*}$ & Glutathione $(\mu \mathrm{mol} / \mathrm{l})^{*}$ \\
\hline Control & $6-8$ & $17.4 \pm 2.7$ & $670.0 \pm 62$ & $28.1 \pm 3.2^{\mathrm{a}}$ & $25.0 \pm 2.5^{\mathrm{a}}$ & $25.5 \pm 7.0^{\mathrm{a}}$ \\
Abnormal & $6-8$ & $18.3 \pm 4.1$ & $658.0 \pm 63.1$ & $41.8 \pm 5.1^{\mathrm{b}}$ & $156.5 \pm 38.4^{\mathrm{b}}$ & $7.6 \pm 0.89^{\mathrm{b}}$ \\
\hline
\end{tabular}

N: No. of cattle examined. * Data were summarized as means \pm SEM of $6-8$ cattle. ${ }^{\text {a-b }}$ Values with different superscripts within the same column differ significantly $(\mathrm{P}<0.05)$.

were matured in $\mathrm{m}$-TCM199, fertilized in $\mathrm{m}-\mathrm{BO}$ and then cultured in $\mathrm{m}$-SOF supplemented with $\operatorname{BHBA}(0,25,50$ or $250 \mathrm{mg} / \mathrm{l})$ or $\gamma$-GTP $(0,50,250$ and $500 \mathrm{IU} / 1)$. The frequencies of embryos undergoing cleavage and developing to the blastocyst stage were determined.

\section{Statistical analysis}

The frequencies of cleavage and development to the blastocyst stage were calculated for every replicate and summarized as means \pm SEM. The numbers and proportions of good quality oocytes and the frequency of development to the cleavage or blastocyst stage were analyzed using $t$-test for Experiment 1 and ANOVA with Fisher's PLSD test for Experiment 2. The compositions of the FF were compared using a $t$-test. A value of $\mathrm{P}<0.05$ was considered significant. The correlations between the blastocyst rate and BHBA and $\gamma$-GTP concentrations were analyzed using Pearson's correlation coefficient with Fisher's r-to-z transformation.

\section{Results}

\section{Experiment 1-1}

The total number of COCs that could be collected from ovaries of the LD group was lower than that of the control group; moreover, the proportion of oocytes with good quality was significantly lower in the LD group than that in the control group $(\mathrm{P}<0.05$; Table 2$)$. The frequency of development to the blastocyst stage was significantly lower in the LD group than in the control group ( $\mathrm{P}<0.05$; Table 2$)$.

\section{Experiment 1-2}

The concentrations of glucose and NEFA in FF of the LD group were the same as those of the normal group (Table 3). However, the concentrations of $\gamma$-GTP and BHBA in FF were significantly elevated in the LD group compared with the control group (Table $3)$. There was a negative correlation between the rates of blastocyst formation and the concentrations of BHBA and $\gamma$-GTP in FF. The correlation coefficient for BHBA was -0.687 ( $\mathrm{P}=0.025$; Fig. 1), and that for $\gamma$-GTP was -0.719 ( $\mathrm{P}=0.001$; Fig. 2). The concentration of glutathione in FF of the LD group was lower than that of the control group (Table 3).

\section{Experiment 2}

We assessed the effects of BHBA and $\gamma$-GTP during IVM of oocytes on their subsequent development after IVF by culturing the COCs from the normal group in IVM medium supplemented with various concentrations of these compounds. We found that neither compound had any effects on cleavage and blastocyst development. However, both compounds during IVC of the embryos significantly reduced the rate of development to the blastocyst stage in a concentration- dependent manner (Tables 4 and 5). Supplementation with more than $50 \mathrm{mg} / 1 \mathrm{BHBA}$ or $50 \mathrm{IU} / 1 \gamma$-GTP reduced the numbers of blastocysts obtained.

\section{Discussion}

Here, we investigated the effect of liver disease on oocyte development in cattle by comparing in vitro development of oocytes obtained from cows with normal or diseased livers. We found that the proportion of good quality oocytes and the frequency of development to the blastocyst stage were lower in the liver anomaly group than those in the control group. Preliminary analyses established that approximately $95 \%$ of the oocytes from cattle of both groups could mature to the metaphase II stage. Likewise, cells from both groups showed a similar rate of successful in vitro fertilization $(80 \%)$. Since each cow provided a limited number of good quality COCs (6-42 COCs/cow), the total number of available COCs restricted our analyses to the developmental potential of oocytes to the blastocyst stage. Initially, as part of Experiment 1, we had planned to collect blood samples to check the physical condition of the dairy cows; however, this proved impractical under the conditions in the slaughterhouse. Thus, we chose an alternative approach of collecting and analyzing FF, as these accurately reflect blood composition [26]. Our analyses of the FF showed that the concentrations of BHBA and $\gamma$-GTP were significantly elevated in cattle judged to have abnormal livers compared with normal, healthy cattle. Moreover, there was a negative correlation between 


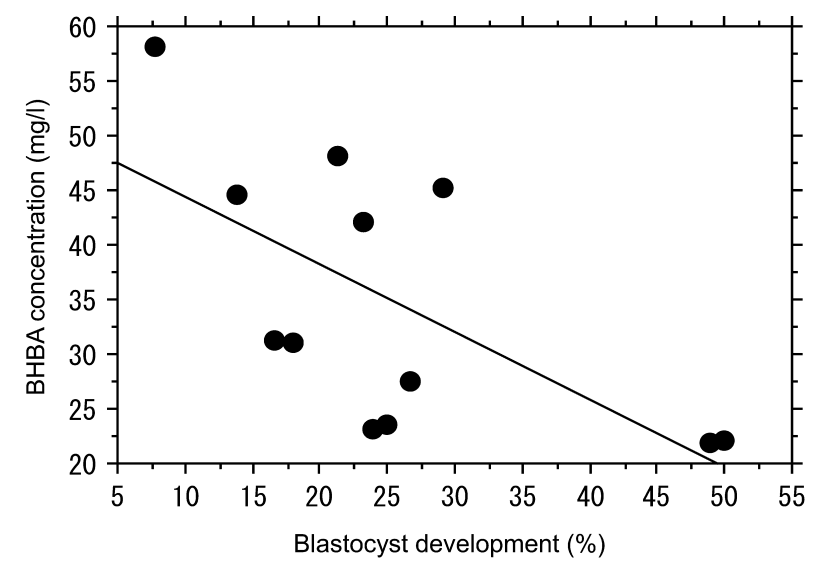

Fig. 1. Analysis of the developmental potential of oocytes in relation to the concentration of BHBA in follicular fluid. There was a significant negative correlation between the rate of blastocyst formation and BHBA concentration. A correlation coefficient of $-0.640(\mathrm{P}=0.025, \mathrm{n}=12)$ was obtained.

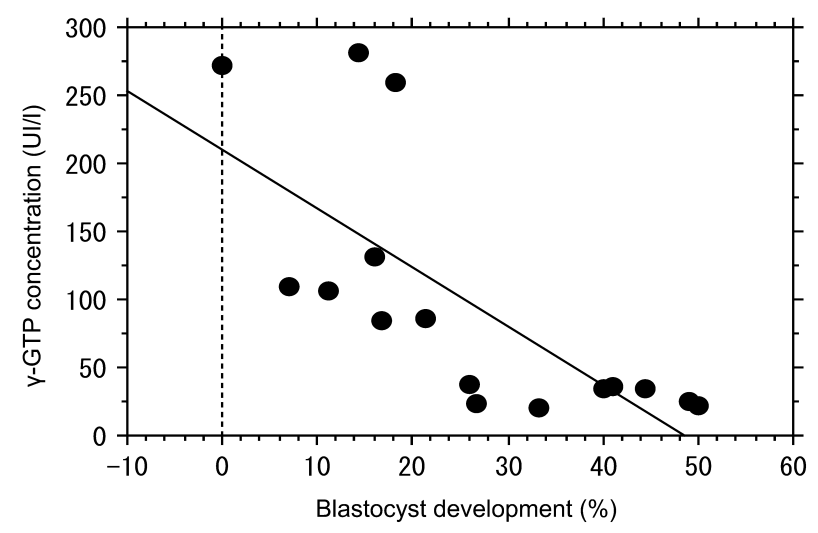

Fig. 2. Analysis of the developmental potential of oocytes in relation to the concentration of $\gamma$-GTP in follicular fluid. There was a significant negative correlation between the rate of blastocyst formation and $\gamma$-GTP concentration. A correlation coefficient of $-0.719(\mathrm{P}=0.001, \mathrm{n}=16)$ was obtained.

the proportion of oocytes that developed to the blastocyst stage and the concentration of BHBA (Fig. 1) and $\gamma$-GTP (Fig. 2). BHBA is a ketone that is found at high concentrations in the blood of dairy cows suffering from ketosis, which easily occurs during NEB [13]. $\gamma$-GTP is also known as a blood marker of liver abnormalities [27, 28]. We, therefore, conclude that there is likely a close relationship between the lower embryonic development competence of oocytes derived from cattle with liver disorders and the high concentrations of BHBA and $\gamma$-GTP.

In Experiment 2, we examined the effect of BHBA and $\gamma$-GTP during IVM of oocytes and IVC of embryos on early embryonic development. We found that both compounds during IVC inhibited embryo development in a concentration-dependent manner. Leroy et al. [29] reported that high concentrations of BHBA and lower concentrations of glucose impair the competence of oocyte develop-
Table 4. Effects of BHBA supplementation on culture of bovine embryos $^{\#}$

\begin{tabular}{lccc}
\hline $\begin{array}{l}\text { Concentration } \\
(\mathrm{mg} / \mathrm{l})\end{array}$ & $\begin{array}{c}\text { No. of } \\
\text { embryos cultured }\end{array}$ & $\begin{array}{c}\text { No. of embryos } \\
\text { cleaved (\%)* }\end{array}$ & $\begin{array}{c}\text { No. of } \\
\text { blastocysts }(\%)^{*}\end{array}$ \\
\hline 0 & 131 & $116(86.8 \pm 2.5)$ & $57(43.4 \pm 1.8)^{\mathrm{a}}$ \\
25 & 131 & $104(79.8 \pm 3.0)$ & $46(35.7 \pm 6.6)^{\mathrm{a}}$ \\
50 & 134 & $112(80.4 \pm 1.4)$ & $28(19.0 \pm 4.0)^{\mathrm{b}}$ \\
100 & 136 & $105(78.3 \pm 6.6)$ & $28(21.1 \pm 5.0)^{\mathrm{b}}$ \\
250 & 136 & $101(73.6 \pm 6.2)$ & $20(14.2 \pm 4.3)^{\mathrm{b}}$ \\
\hline
\end{tabular}

\# Data from 5 replicates. *Percentages of cultured embryos represent means \pm SEM. ${ }^{\mathrm{a}-\mathrm{b}}$ Values with different superscripts differ significantly $(\mathrm{P}<0.05)$.

Table 5. Effects of $\gamma$-GTP supplementation on culture of bovine embryos ${ }^{\#}$

\begin{tabular}{lccc}
\hline $\begin{array}{l}\text { Concentration } \\
\text { (IU/1) }\end{array}$ & $\begin{array}{c}\text { No. of } \\
\text { embryos cultured }\end{array}$ & $\begin{array}{c}\text { No. of embryos } \\
\text { cleaved (\%)* }\end{array}$ & $\begin{array}{c}\text { No. of } \\
\text { blastocysts }(\%)^{*}\end{array}$ \\
\hline 0 & 170 & $141(85.1 \pm 3.8)$ & $54(32.2 \pm 3.7)^{\mathrm{a}}$ \\
50 & 170 & $124(71.8 \pm 3.3)$ & $35(19.8 \pm 5.0)^{\mathrm{b}}$ \\
250 & 170 & $132(76.1 \pm 7.0)$ & $29(15.5 \pm 5.1)^{\mathrm{bc}}$ \\
500 & 161 & $125(76.6 \pm 3.8)$ & $15(9.1 \pm 3.2)^{\mathrm{c}}$ \\
\hline
\end{tabular}

\# Data from 6 replicates. * The percentages of cultured embryos represent means \pm SEM. ${ }^{a-b}$ Values with different superscripts differ significantly $(\mathrm{P}<0.05)$.

ment after maturation. Plasma BHBA concentrations combined with plasma glucose values were used to classify cows with poor energy status [30]. However, dairy cattle with subclinical ketosis can become ketonemic without the presence of significant hypoglycemia [31]. Under aerobic conditions in the citric acid cycle, BHBA may be utilized as an energy source for several cell types [32]. Early bovine embryos have been shown to be capable of using BHBA as an alternative energy source [33].

Leroy et al. [29] suggested that it was unlikely that COCs could use BHBA as an alternative energy source because addition of BHBA to a maturation medium with a low glucose concentration did not ameliorate a reduced rate of cleavage and blastocyst formation. In cumulus cells, glucose is predominantly metabolized via the glycolytic pathway to produce pyruvate and lactate, which are the preferred substrates for the oocyte to produce ATP [34]. As BHBA is present as acetyl $\mathrm{CoA}$ in the Krebs cycle, these pyruvate and lactate molecules cannot be produced from BHBA [29]. BHBA was previously reported to be one of the ketones that increase in the blood during ketosis and fatty liver disease and other energy-related diseases [35-37]. Therefore, it is thought that high levels of BHBA transiting into FF suppress the glycolytic pathway and put the oocyte into an energy-shortage condition that decreases its competence to support early embryonic development.

$\gamma$-GTP is the enzyme responsible for the extracellular catabolism of glutathione, and is important in the maintenance of intracellular glutathione concentrations [38, 39]. Reduced glutathione (GSH) plays a wide and important role in anti-oxidative activities in vivo [40, 41]. Oocytes contain high concentrations of GSH that protect the cells and resultant embryos from oxidative stress during fertilization and early embryo development [42]. In Experiment 1-2, we determined 
the concentration of glutathione in the FF and found that it was lower in the LD group than in the control group. In Experiment 2, supplementation of $\gamma$-GTP to the culture medium at a concentration higher than $50 \mathrm{IU} / 1 \gamma$-GTP inhibited early development of the embryos. These results indicate that a hyper-concentration of $\gamma$-GTP in FF causes a reduced concentration of glutathione both in oocytes and embryos, resulting in a decrease in anti-oxidative capability in the resultant embryos.

In Experiment 2, BHBA or $\gamma$-GTP during IVM had no effect on subsequent embryo development. This result was contrary to the results of Experiment 1, in which oocytes from follicles of cattle with liver abnormalities and with elevated levels of BHBA or $\gamma-\mathrm{GTP}$ showed low developmental potential. Iwata et al. [43] also found a slowed progression to metaphase II in oocytes of cattle with liver abnormalities. Oocytes are exposed to some detrimental substances in the FF for 7-10 days of follicular growth and maturation in vivo, a period obviously considerably longer than the $24 \mathrm{~h}$ for in vitro maturation of oocytes. This difference in the length of time exposed to detrimental substances, such as BHBA and $\gamma$-GTP, may explain the differences in the results.

In conclusion, we show here that the proportion of good quality oocytes and their developmental potential were lower in dairy cattle with abnormal livers than those in healthy cattle and highlight the possible influence of elevated concentrations of BHBA and $\gamma$-GTP in the FF as a detrimental factor in reproduction.

\section{Acknowledgements}

The authors thank Genetics Hokkaido Association for providing the frozen semen, Chikusei Meat Center and Nakao Chikusan Co., Ltd. for providing the ovaries used in this study and Yamanashi Prefecture and Ibaragi Prefecture for providing the data on the slaughtered cattle.

\section{References}

1. Seshagiri PB, Bavister BD. Phosphate is required for inhibition by glucose of development of hamster 8-cell embryos in vitro. Biol Reprod 1989; 40: 607-614. [CrossRef] [Medline]

2. Lim JM, Hansel W. Roles of growth factors in the development of bovine embryos fertilized in vitro and cultured singly in a defined medium. Reprod Fertil Dev 1996; 8: 1199-1205. [CrossRef] [Medline]

3. Fukui Y, Kikuchi Y, Kondo H, Mizushima S. Fertilizability and developmental capacity of individually cultured bovine oocytes. Theriogenology 2000; 53: 1553-1565. [CrossRef] [Medline]

4. Lee ES, Fukui Y, Lee BC, Lim JM, Hwang WS. Promoting effects of amino acids added to a chemically defined medium on blastocyst formation and blastomere proliferation of bovine embryos cultured in vitro. Anim Reprod Sci 2004; 84: 257-267. [CrossRef] [Medline]

5. Nagao Y, Iijima R, Saeki K. Interaction between embryos and culture conditions during in vitro development of bovine early embryos. Zygote 2008; 16: 127-133. [CrossRef] [Medline]

6. Hagemann LJ, Beaumont SE, Berg M, Donnison MJ, Ledgard A, Peterson AJ, Schurmann A, Tervit HR. Development during single IVP of bovine oocytes from dissected follicles: interactive effects of estrous cycle stage, follicle size and atresia. Mol Reprod Dev 1999; 53: 451-458. [CrossRef] [Medline]

7. Machatková M, Jokesová E, Petelíková J, Dvorácek V. Developmental competence of bovine embryos derived from oocytes collected at various stages of the estrous cycle. Theriogenology 1996; 45: 801-810. [CrossRef] [Medline]

8. Lonergan P, Monaghan P, Rizos D, Boland MP, Gordon I. Effect of follicle size on bovine oocyte quality and developmental competence following maturation, fertilization and culture in vitro. Mol Reprod Dev 1994; 37: 48-53. [CrossRef] [Medline]

9. Wit AA, Wurth YA, Kruip TA. Effect of ovarian phase and follicle quality on morphology and developmental capacity of the bovine cumulus-oocyte complex. J Anim Sci 2000; 78: 1277-1283. [Medline]

10. Tanghe S, Van Soom A, Mehrzad J, Maes D, Duchateau L, Kruif A. Cumulus contributions during bovine fertilization in vitro. Theriogenology 2003; 60: 135-149. [CrossRef] [Medline]

11. Thompson JG, Lane M, Gilchrist RB. Metabolism of the bovine cumulus-oocyte complex and influence on subsequent developmental competence. Soc Reprod Fertil Suppl 2007; 64: 179-190. [Medline]

12. Nielen M, Aarts MGA, Jonkers AGM, Wensing T, Schukken YH. Evaluation of two cowside tests for the detection of subclinical ketosis in dairy cows. Can Vet $J 1994$; 35: 229-232. [Medline]

13. González FD, Muiño R, Pereira V, Campos R, Benedito JL. Relationship among blood indicators of lipomobilization and hepatic function during early lactation in high-yielding dairy cows. J Vet Sci 2011; 12: 251-255. [CrossRef] [Medline]

14. Ametaj BN. A new understanding of the causes of fatty liver in dairy cows. Adv Dairy Technol 2005; 17: 97-112.

15. Lucy MC. Reproductive loss in high-producing dairy cattle: where will it end? J Dairy Sci 2001; 84: 1277-1293. [CrossRef] [Medline]

16. Gröhn YT, Rajala-Schultz PJ. Epidemiology of reproductive performance in dairy cows Anim Reprod Sci 2000; 60: 605-614. [CrossRef] [Medline]

17. Nagao Y, Harada Y, Yamaguchi M, Igarashi A, Ooshima Y, Kato Y. Antioxidant treatment during preservation of bovine ovaries increased the development potential of embryos. Zygote 2010; 18: 315-321. [CrossRef] [Medline]

18. Nagao Y, Saeki K, Hoshi M, Kainuma H. Effects of oxygen concentration and oviductal epithelial tissue on the development of in vitro matured and fertilized bovine oocytes cultured in protein- free medium. Theriogenology 1994; 41: 681-687. [CrossRef] [Medline]

19. Brackett BG, Oliphant G. Capacitation of rabbit spermatozoa in vitro. Biol Reprod 1975; 12: 260-274. [CrossRef] [Medline]

20. Nagao Y, Saeki K, Hoshi M, Takahashi Y, Kanagawa H. Effects of water quality on in vitro fertilization and development of bovine oocytes in protein-free medium. Theriogenology 1995; 44: 433-444. [CrossRef] [Medline]

21. Miwa I, Okuda J, Maeda K, Okuda G. Mutarotase effect on colorimetric determination of blood glucose with D-glucose oxidase. Clin Chim Acta 1972; 37: 538-540. [CrossRef] [Medline]

22. Shimizu S, Yasui K, Tani Y, Yamada H. Acyl-CoA oxidase from Candida tropicalis Biochem Biophys Res Commun 1979; 91: 108-113. [CrossRef] [Medline]

23. Parry AEJ, Robinson DS, Wedzicka BL. An enzymic assay for $\beta$-hydroxybutyric acid in liquid whole egg. J Sci 1980; 31: 905-910.

24. Szasz G. A kinetic photometric method for serum $\gamma$-glutamyl transpeptidase. Clin Chem 1969; 15: 124-136. [Medline]

25. Orlowski M, Alton M. $\gamma$-Glutamyl-p-nitroanilide: A new convenient substrate for determination and study of $\mathrm{l}-$ and d- $\gamma$-glutamyltranspeptidase activities. Biochim Biophys Acto 1963; 73: 679-681. [CrossRef] [Medline]

26. Leroy JL, Vanholder T, Delanghe JR, Opsomer G, Van Soom A, Bols PE, Dewulf J, de Kruif A. Metabolic changes in follicular fluid of the dominant follicle in high yielding dairy cows early postpartum. Theriogenology 2004; 62: 1131-1143. [CrossRef] [Medline]

27. Jun HJ, Lee KG, Lee YK, Woo GJ, Park YS, Lee SJ. Correlation of urinary furan with plasma gamma-glutamyltranspeptidase levels in healthy men and women. Food Chem Toxicol 2008; 46: 1753-1759. [CrossRef] [Medline]

28. Minervino AH, Barrêto Júnior RA, Queiroz GF, Headley SA, Ortolani EL. Predictive values of aspartate aminotransferase and gamma- glutamyl transferase for the hepatic accumulation of copper in cattle and buffalo. J Vet Diagn Invest 2008; 20: 791-795. [CrossRef] [Medline]

29. Leroy JL, Vanholder T, Opsomer G, Van Soom A, De Kruif A. The in vitro development of bovine oocytes after maturation in glucose and beta-hydroxybutyrate concentrations associated with negative energy balance in dairy cows. Reprod Domest Anim 2006; 41: 119-123. [CrossRef] [Medline]

30. Whitaker DA, Kelly JM, Smith EJ. Subclinical ketosis and serum ketotic dairy cows. $\mathrm{Br}$ Vet J 1983; 139: 462-463. [Medline]

31. Gröhn Y, Lindberg LA, Bruss ML. Fatty infiltration of liver in spontaneously betahydroxybutyrate levels in dairy cattle. J Dairy Sci 1983; 66: 2320-2328. [Medline]

32. Veech RL. The therapeutic implications of ketone bodies: the effects of ketone bodies in pathological conditions: ketosis, ketogenic diet, redox states, insulin resistance, and mitochondrial metabolism. Prostaglandins Leukot Essent Fatty Acids 2004; 70: 309-319. [CrossRef] [Medline]

33. Gómez E, Duque P, Díaz E, Facal N, Antolín I, Hidalgo C, Díez C. Effects of acetoacetate and D-beta-hydroxybutyrate on bovine in vitro embryo development in serum-free medium. Theriogenology 2002; 57: 1551-1562. [CrossRef] [Medline]

34. Cetica P, Pintos L, Dalvit G, Beconi M. Activity of key enzymes involved in glucose and triglyceride catabolism during bovine oocyte maturation in vitro. Reproduction 2002; 124 
675-681. [CrossRef] [Medline]

35. Grummer RR. Impact of changes in organic nutrient metabolism on feeding the transition dairy cow. J Anim Sci 1995; 73: 2820-2833. [Medline]

36. Herdt TH. Ruminant adaptation to negative energy blance: Influences on the etiology of ketosis and fatty liver. Vet Clin North Am Food Anim Pract 2000; 16: 215-230. [Medline]

37. Duffield T, Bagg R, DesCoteaux L, Bouchard E, Brodeur M, DuTremblay D, Keefe G, LeBlanc S, Dick P. Prepartum monensin for the reduction of energy associated disease in postpartum dairy cows. J Dairy Sci 2002; 85: 397-405. [CrossRef] [Medline]

38. Dominici S, Paolicchi A, Lorenzini E, Maellaro E, Comporti M, Pieri L, Minotti G, Pompella A. Gamma-glutamyltransferase-dependent prooxidant reactions: a factor in multiple processes. Biofactors 2003; 17: 187-198. [CrossRef] [Medline]
39. Whitfield JB. Gamma glutamyl transferase. Crit Rev Clin Lab Sci 2001; 38: 263-355. [CrossRef] [Medline]

40. Shan H, Aw TY, Jones DP. Glutathione dependent protection against oxidative injury. Pharmacol Ther 1990; 47: 61-71. [CrossRef] [Medline]

41. Meister A. Glutathione metabolism and its selective modification. J Biol Chem 1988; 263 17205-17208. [Medline]

42. Luberda Z. The role of glutathione in mammalian gametes. Reprod Biol 2005; 5: 5-17. [Medline]

43. Iwata H, Tanaka H, Kanke T, Sakaguchi Y, Shibano K, Kuwayama T, Monji Y. Follicle growth and oocyte developmental competence in cows with liver damage. Reprod Domest Anim 2010; 45: 888-895. [Medline] 